\title{
From Handicraft to Technologies: Historical Development of Handicraft Education in General Schools in Lithuania
}

\author{
Zivile Sederevičiūtè-Pačiauskienè ${ }^{1 *}$, Ilona Valantinaite ${ }^{1}$, Viktorija Žilinskaitè-Vytienè ${ }^{1}$ \\ ${ }^{1}$ Vilnius Gediminas Technical University, LITHUANIA
}

Received 13 January 2019 • Revised 15 March 2019 • Accepted 27 May 2019

\begin{abstract}
Technologies is one of the subjects in general education that have been influenced by political, economic, technological, social and cultural developments. The teaching of this practical subject has been a historical component of the curriculum for many decades. This reflected the needs of society to provide the younger generation with the skills and knowledge necessary to ensure their smooth integration into the labour market. During specific periods, the content of the subject did not change significantly, despite historic disruptions in the economic, political and cultural context and these were reflected in the guidelines of Technologies programs. This has been demonstrated in the analysis of content of general education programmes and textbooks of Technologies in Lithuania.

From the time the subject was introduced, pupils were taught practical skills for employment in industry, as well as to perform household work and promote traditional Handicraft. State institutions steered Lithuanian public education towards industryoriented, manual training and attempted to direct Lithuanian girls and boys into industrial production. However, the textbooks reflect the traditional view of what Lithuania's people needed, namely basic knowledge of how to manage domestic life, and promote Handicraft and national traditions.
\end{abstract}

Keywords: handicraft, technologies education, textbooks, practical education, creativity, curriculum

\section{INTRODUCTION}

In the nineteenth century, ideas arose concerning the practical application of crafts as a means of facilitating public education in Europe, based on general pedagogical goals (Thorsteinsson \& Ólafsson, 2014). Handicraft found its place in the national curriculum of various countries in different time, but the necessity of it was not disputed. Scientists explain the origin of the subject differently, however most agree that Danish sloyd pedagogy gave a beginning to use craft as a tool in general education. Sloyd pedagogy was initiated by the Finn Uno Cygnaeus (1810 - 1888) and the Swede Otto Salomon (1849-1907), along with Dannish Aksel Mikkelsen (1849 -1929). Uno Cygnaeus began Handicraft education in the 1830s in St. Petersburg where Handicraft were taught in Petri-school, the school for the Finnish children. According to Uno Cygnaeus Handicrafts was one of the main subjects in the school and it needed for education of an independent and rational human being (Kantola at all, 1999). The Sloyd system was meant to empower people in the self-sufficiency of their homes and provide young craftsmen with the opportunity to sustain a living through woodwork (Thorsteinsson \& Ólafsson, 2014).

Sloyd system developed into an independent subject in many European countries. Finland was the first country in the world to establish Craft as a compulsory subject in $1866^{1}$ and the founder of the subject, Uno Cygnaeus, is referred to as the father of Technology Education (Kantola et al., 1999). The famous handwork classes were

1 1809-1917 Finland was incorporated into the Russian Empire as the autonomous Grand Duchy of Finland.

(C) 2020 by the authors; licensee Modestum Ltd., UK. This article is an open access article distributed under the terms and conditions of the Creative Commons Attribution License (http://creativecommons.org/licenses/by/4.0/). $\square$ zivile.sedereviciute-paciauskiene@vgtu.It (*Correspondence) $\boldsymbol{B}$ ilona.valantinaite@vgtu.It 


\section{Contribution of this paper to the literature}

- The investigation of the content of Handicraft shows the changes in the handicraft education and allows to make a presumption if the changes are sufficient to reflect the needs of nowdays society.

- The article demonstrates the content of handicraft and technology textbooks in different geopolitical periods in Lithuania as well as the goals that the national technology curriculum raised for the Handicraft school subject.

- The content of Handicraft in Lithuania was differentiated by gender since its very introduction into the national curriculum of the country. As part of a long-standing tradition, girls were taught domestic work, and boys woodworking and metalworking, as well as the operation of electrical appliances. Yet, Technogies subject provides the mutual content to boys and girls.

operating in Nääs town of Sweden in 1872 (Kantola at all, 1999). A representative school with compulsory handwork training was established in Paris 1873 (Galkauskas, 2004). The Subject Handicraft was introduced to the school programs of general schools in Latvia in $1874^{2}$ (Urdzina-Deruma, 2006). So-called labour school (Arbeitsschule) pioneered in 19th century in Germany introducing the manual work to the education (Herbs, 2006). The compulsory subject Handarbeit was introduces in to the general education of Germany in 1886 (Galkauskas, 2004). Handwork was introduced as the compulsory subject in to the technical schools of United States in 1876, after Philadelphia exhibition, and in to the general school curriculum in 1898, when Mr. Larsson, who was trained by Otto Salomon, moved to the U.S. and founded in 1888 the 'Boston Sloyd School' (Kantola, et al., 1999). The subject called Manual training was introduced in to England general education in 1894 (Kantola, et al., 1999). The same year Craft as a general educational subject has been included in the Estonian Curriculum for General Education School 3(Lind, 2009). Yet, in Island handicraft was not included as a compulsory subject until 1936 (Thorsteinsson, 2009).

At the time teaching was based on the principles of the so-called labour school principles, which state that including craft in the curriculum should aid students in becoming more independent and the school in becoming more viable (Lind, 2009).

The first law concerning compulsory education was introduced in Lithuania in 1922, however it was implemented only in 1928. Handicraft was introduced into the general education programme of Lithuanian schools in 1928 (Ruzgas, 1928). Handicraft was one of the subjects of general education, the content of which was mostly influenced by political, economic, technological, social and cultural development. It was a practical subject at school, which provided pupils with basic knowledge and skills needed for their life in society. The content of Handicraft in Lithuania was differentiated by gender since its very introduction into the national curriculum of the country (The work (technological) education, 2005). As part of a long-standing tradition, girls were taught domestic work, and boys woodworking and metalworking, as well as the operation of electrical appliances.

Several scholars have investigated historical change of Handicraft at school (Galkauskas, 2004; Kantola et al., 1999; Taar, 2017; Urbietis, 2005; Urdzina-Deruma, 2006). The content of Handicraft subjects was the objective of quite a few studies as well (Lind, 2009, 2012; Numgaudienė \& Žygaitienė, 2014; Pöllänen \& Urdziņa-Deruma, 2017; Statauskienè, 2009; Thorsteinsson et al., 2009; Turkki, 2012; Valantinaite \& Žilinskaitė, 2012). However, there is a lack of research of historical development of Handicraft education in general school in Lithuania, where the Handicraft subject had a dramatic shift from the Crafts to Technologies education.

In many European countries home economics and technologies, household study subject decreased or disappeared at all and the ancient handicrafts forms and ethnographic heritage is no longer considered as a priority (Dislere, 2012). Lithuania, a small country of the European Union, which has maintained the subject of Handicrafts in school content and used it in a specific way, while in many countries this subject has been eliminate from the national curriculum. The content of the subject in Lithuania has changed, the consumer's perspective has diminished and an industrial approach has emerged. In modern society, it is necessary to teach the youth about technologies and to introduce them innovations. Yet, it is not less important to maintain the subject in the curriculum which provides students necessary life skills, cherish national traditions and teach how to deal with challenges of globalization. Lithuania has chosen the way to merge crafts and technologies and to maintain the subject in the national curriculum that integrates the knowledge from nearly all school subjects and that helps students to deal with the challenges of career as well as of daily life. Since 2003 the subject title was changed to Technologies and the subject is beeing tough in all grades of Lithuanian school.

The investigation of the content of Handicraft/Technologies will show the essential changes in the Handicraft education in Lithuania and allow to make a presumption if the changes are sufficient to reflect the needs of nowdays

2 1721-1918 Latvia was incorporated into the Russian Empire.

3 1710-1917 Estonia was incorporated into the Russian Empire. 
society. We have chosen the documents of national curriculum of Handicraft and of Technologies since the time the title was changed as well as textbooks of this subject for the analysis of the content of Handicraft and of Technologies. The importance of the content analysis of textbooks lies in the fact that a textbook is one of the factors that influence a teacher's work in the classroom (Bruzgelevičienė, 2008). Textbooks are important teaching aids and sources from which students of all schooling years obtain knowledge (Yang \& Myint, 2016) and reflect curricula (Stromquist, 1989). School textbooks are important educational tools conveying educational content and assisting in seeking high-quality teaching/learning, developing a system of values among pupils and creating a cultured society of educated people (Cibulskaite \& Baranovska, 2009). A study by Sadker and Zittleman (2007, p. 144) showed that students spent as much as 80 to 95 percent of classroom time using textbooks and that teachers based the majority of their instructional decisions on the textbook. Although today pupils have many sources of information, textbooks were for long the only source or one of the main sources. However, in practical school subjects, such as Handicraft, a textbook is most often a compass of the content for the teachers even now. On the one hand we can examine the content of Handicraft/Technologie s as a reflection of the relevant content of education, which enables us to understand a taken-for-granted knowledge of the era (things that have to be known by everyone or at least by the majority of the epoch's people (Schutz \& Luckmann, 1973). On the other hand, we may examine the content of Handicraft textbooks as the reflection of an epochal attitude towards functions attributed to a gender. Gender bias in texts usually involves a common pattern: studies from the whole gamut of developing and developed countries have found that females tend to be greatly under-represented, that both males and females are depicted in such gender-stereotyped ways, and that girls' and boys' visions of who they are and what they can become are constrained (Blumberg, 2007). The content of Handicraft taught in Lithuania was differentiated by gender since its very introduction into the national curriculum of the country. As part of a longstanding tradition, girls were taught domestic work, and boys woodworking and metalworking, as well as the operation of electrical appliances. It is common in a vast majority of gender bias studies that 'both genders were shown in highly gender-stereotyped ways in the household as well as in the occupational division of labor, and in the actions, attitudes and traits portrayed (Blumberg, 2007).' This article analyzes the course content of Handicraft training for boys and girls and its changing nature over time. However, it makes no link with prevailing stereotypes.

\section{RESEARCH METHODOLOGY}

This paper reveals the essential changes in the content of the Handicraft/Technology textbooks and the national curriculum of Lithuanian general education in 1918 - 2017.

The data was interpreted in light of a theoretical framework grounded in the scholarly literature to address relevant research questions. What was the content of hadicraft and technology textbooks in different geopolitical periods in Lithuania? What goals did the national curriculum raised for the Handicraft school subject? How did the content of the textbooks reflect the objectives of the national curriculum? How has the content of Handicraft changed and what the goals it has today?

Based on the qualitative research strategy, the documentary research method (McCulloch, 2004) is being used. The data were accumulated in accordance with the principles of authenticity, reliability and representativity. All documents of national curriculum of general education were selected for the primary reading of documentary sources. In this stage of reading, a preliminary evaluation of the content was made and the decision was made whether the source could be selected for further analysis (Gerrard, 2004). The textbooks were selected by analysing the Lithuanian National Bibliographic Database. All available documents of Handicraft and Technologies national curriculum and all textbooks of the subject in Lithuania issued since 1918 were used for the study. Content analyses was carried out according Philipp Mayring (2000).

The overview of the content development of Handicraft is given by the principle of historical consistency: the period of the Fist Republic of Lithuania (1918-1940), the Soviet times (1939-1941, 1945-1987) and Lithuania after the restoration of independence (from 1990 until 2017).

\section{FINDINGS}

\section{Historical Origins of Handicraft}

The historiography, which reveals Handicraft teaching issues in Lithuania in the period 1918-1930, is scant. The beginnings of manual work at the primary stages of general education were highlighted in the scientific works of Meilè Lukšienè (Lukšienè, 1970; Lukšienè \& Jonynienè, 1992). Manual work as an educational objective embraced several forms of the teaching of agriculture, gardening and crafts (Lukšienè, 1970). Holistic personality development was linked to a harmonious and comprehensive development of mental and physical powers and abilities in pupils, owing to which Handicraft was introduced into the curriculum as a separate educational subject (Ruzgas, 1928). 
The beginning and development of Handicraft education in Lithuania is associated with the name of Vincas Ruzgas (1890 - 1972). Vincas Ruzgas was a prominent figure in culture and education of Lithuania. He was a teacher, methodologist, author of many textbooks, translator and one of the pioneers of librarianship in Lithuania. V. Ruzgas highlighted the necessity of gardening and horticultural works in rural schools where future farmers were studying. The author gave concrete advice on how to use school parcels for teaching purposes (Bernotas, 1997). The first Lithuanian handwork textbooks by V. Ruzgas, 'Carboard and Bookbinding Textbook' (1926) and 'Metalworking and Woodworking' (1930), impacted strongly on the development of Handicraft content (Siriakoviene, 1991). He's textbooks ideas were based on Komensky, Russo, Pestalocio had a tremendous influence on V. Ruzgas works and textbooks as well as on the Handcrafts education in Lithuania (Bernotas, 1997). V. Ruzgas in he's article "Learning the ways of examining nature" wrote: “...the worst side of old school was that it used to suppress the children's liberty and initiative" (1929). He was encouraging teachers to give children some easy manual work tasks along with math and writing.

When the manual work was introduced to Lithuanian primary school (age 7-11), metalworking and woodworking were reserved for boys, and Handicraft and needlework for girls. V. Ruzgas offered schools the following Handicraft content: 1) paper and cardboard work, 2) sculpting, 3) metalworking, 4) woodworking, 5) Handicraft and needlework, 6) gardening and horticulture (Širiakovienè, 1991). Lithuania experienced large internal and external economic and political shocks in the third and fourth decades of XX century. The global economic crisis, blocked export of Lithuanian production caused shortage in the country (Raipa, Smalskys, 2003).

After 1936, further to the school reform, the primary school was reorganized from 4 to 6 grade school. Only girls were thought Handicraft and only in the first to sixth forms of gymnasium. The educational content consisted of knitting, weaving, embroidery, sewing and domestic, household and culinary work (Urbietis, 2005). In 1936, separate versions of the programme for urban and rural schools were drawn up. In urban schools, attention was devoted to mathematics, foreign languages and manual work, whereas in rural schools the focus was on agriculture (Vaičiulienè, 1973). Manual work teaching was important for both genders. Even the curriculum was ment to be equal for both boys and girls, however, the educational content of the lessons was differed in accordance with the activities, which, at that time, were deemed to be normal for men and women.

In 1940 the occupation and annexation of Lithuania, Latvia and Estonia by the Soviet Union interrupted the statehood of these countries. For socio-political, economic and ideological reasons, the Soviet authorities in Lithuania devoted much time and effort to entrench women's rights. To this end, propaganda and policy were used to great effect in an effort to liberate women from more traditional roles. The Soviet proposition was simple enough: the inequality of women no longer existed because 'women were now entitled to work together with men, and they must therefore be grateful to the Soviet authorities' (Jureniene, 2009). Since all spheres of industry experienced labour shortages, the emancipation of women could now provide equal opportunities for men and women, which in turn influenced school curriculum.

The systematic destruction of all areas of the Republic's life, including the destruction of the educational system and the rapid sovietisation of political, social, economic, cultural and spiritual life of the countries (Stašaitis, 2008). No data on Handicrafts textbooks published during that period has been found.

During 1954-1955 practical subject of Handicraft was introduced in the first to fourth forms, during 1955-1956 - in the fifth to sixth forms, and a year later in the seventh form as well. In 1957, a school subject called Works (Darbeliai) became a compulsory subject in the first to fourth forms. The change in Handicraft teaching methodology was regulated by the Soviet Union's Academy of Pedagogical Sciences and the relevant ministry, whereas in Lithuania, the programmes of general education subjects (including Handicraft) followed in the whole of the Soviet Union were adapted to suit the needs of the schools of the Republic of Lithuania (Galkauskas, 2004). Material resources did not meet the needs of the school at that time; there was a lack of teachers and textbooks. The explicit goal was to rebuild all spheres of industry in Soviet Union following the catastrophic wartime years. During this period, a great deal of attention was paid to the work education of pupils. The aim was to involve pupils in to socalled beneficial work for the society. This led to the introduction of new school subjects, increased number of practical training. The industrial training was gradually introduced. Schools started to arrange special laboratory classes, workshop cabinets. The ninth - eleventh forms pupils had to work in companies, factories, collective farms or elsewhere to acquire practical work skills. In the history of Handicraft teaching in Lithuania, 1954-1989 marked the period of polytechnic and industrial training (Urbietis, 2005).

In 1960, a textbook titled 'Handwork for the 5-8th forms', by E. Binkauskienè was published. It intended to teach girls the life skills and to prepare them for solving individual problems. The use and content of the textbook was planned as follows: 5th form - sewing, the kitchen; 6th form - flat tidying and care, flat insulation, indoor flowers and their care, maintenance of cleanliness and order in the flat, elimination of parasites, room cleaning with natural products, laundering, cooking, sewing; 7th form - maintenance of clothing, laundering, cooking, knitting with knitting needles, sewing; 8th form - cooking, sewing (Binkauskienė, 1960). Thus, clearly, the content of this textbook was oriented only towards girls and teir preparation for the maintaining the haushold. However, the 
purpose of the teaching of Handicraft (in 1961) was 'to develop abilities and skills in pupils, process wood and metal, perform <...> electrical installation works, familiarise pupils with blacksmithery - assembly works, the processing of wood and metal, lathing and cutting machines, housework, the agrotechnics of the most important agriculture crops' (Urbietis, 2005). The programmes for Handicraft envisaged the teaching of agriculture to boys and the basics of machinery science and electrical engineering in the eighth to eleventh forms; pupils were sent for practical training to factories and agricultural enterprises. Boys gained knowledge of mechanisms, machinery and electrical appliances in order to learn to use them. It was the beginning of the industrial and technological preparation of pupils, and teaching was geared towards meeting at least the minimum qualification expected of a worker. Nevertheless, there was no industrial training, the preparation of girls for industrial production and agriculture in the textbook. Although the textbook failed to meet the main objectives that were declared in the general programmes, it was republished for a few years following its introduction.

The creators of the programmes of that time wrote: 'We had to manoeuvre between ever-changing handwork curricula of the Soviet Union and Lithuanian ones. We succeeded in creating effective handwork curricula, catering to the needs of practical education and corresponding to the specificity of the Republic of Lithuania, national traditions related to folk art and national Handicraft' (Galkauskas, 2004). The latter aspects were perhaps reflected in the textbooks most notably.'

During the period 1972-1978, the general programmes outlined the objective of teaching Handicraft as being to prepare pupils for both industrial work and independent living in domestic life. However, an analysis of the Domestic Handwork textbooks for the fifth, sixth, seventh and eighth forms, which were published at that time (E. Binkauskienè ‘Domestic Work for the 5th form' (1972), E. Binkauskiene 'Domestic Work for the 6th form' (1973), J. Galkauskas et al. 'Domestic Work for the 7th form' (1974), J. Galkauskas et al. 'Domestic Work for the 8th form' (1975)), shows that their contents hardly differed from those of textbooks published in 1960. The content of textbooks consisted of cooking, working with fabric, apartment lighting, flower growing, crochet, knitting and household tidying. Although the general programmes declared that preparing pupils for industrial production was their objective, the impact on the content of textbooks, and consequently on the educational content at school, was minor. For example, the chapter 'Cooking' in the textbook for the fifth form had a couple of sentences about public catering, the storage of products and occupational safety. A chapter of the textbook for the sixth form, 'Furnishing of a Flat and Its Care', described the electrical installation works of the electrical grid, which may be relevant in the context of the household, but not in that of industrial production. The chapter 'Tree, Shrub and Flower Planting' depicted the greening work and its specificity. Thus, the content consisted of themes aimed at teaching domestic handwork and the development of personal life skills, but described only a few trades. It is worth noting that the trades described were clearly associated with a corresponding gender; for example, floriculture and cooking were qualified as female trades, and electrical installation works as male ones. However, the differentiation was unofficial, and reflected only in the textbooks. Nevertheless, the content of the programmes was assigned to both boys and girls, whereas lessons were being taught without differentiating genders.

Commencing in the mid-1950s, Lithuania underwent a period of rapid industrialisation which placed demands on the school curriculum. Modernization also corresponded with the need to prepare the workforce for newly emerging industries such as chemistry, radio-technics, nuclear industry, etc., as well as agriculture and related areas. Even the teaching of Handicrafts in schools did not go unnoticed, with an administrative directive in 1977 setting out guidelines for the vocational training of pupils.

For the first time, different contents were officially created for boys and girls (Urbietis, 2005). From 1980 to 1987, the following Domestic Handwork textbooks were published: E. Binkauskienè 'Domestic Work for the 5th form' (1980), E. Binkauskienė et al. 'Domestic Work for the 6th form' (1985). J. Galkauskas et al. 'Domestic Work for the 7th form' (1983), J. Galkauskas et al. 'Domestic Work for the 8th form' (1984)). The content of textbooks was adapted to girls. The content structure of Domestic Handwork textbooks for the fifth to eighth forms remained similar to the structure of the textbooks published earlier. The content of the textbooks for all forms consisted of cooking (culinary work), working with fabric, sewing, knitting with pins, knitting with a crochet hook, electrical installation works, furnishing a flat and its care, maintenance of clothing and its mending. Unlike earlier textbooks, the new ones contained a chapter called 'The Elements of Machinery Science'. However, this chapter, as in the textbooks of the previous edition, dealt only with household sewing machines, their parts and repairing of their defects. It seems that although both teachers and textbook authors were required to cling to the ideas of vocational training, they adhered to their own line of thinking - to teach whatever was most necessary to their epoch, and not to the industrial future of society as envisaged by the Soviet Union. Handwork textbooks were filled with knowledge, which enabled girls not so much to prepare for their future trade as to learn to manage their households, to take care of nature and develop their creativities.

The series of textbooks called 'Technical Works', published in 1978-1987, was aimed at boys (Jasaitis 'Technical Works for the 4-6th forms' (1978); J. Jasaitis, K. J. Galkauskas 'Technical Works for the 4th-6th forms' (1985); K. J. Galkauskas, A. Zybartas 'Technical Works for the 7th form' (1986a; 1986b); K. J. Galkauskas, A. Zybartas ‘Technical 
Table 1. The changes in the content of handwork / technology textbooks

\begin{tabular}{|c|c|c|c|c|c|c|c|c|c|c|}
\hline $\begin{array}{l}\text { Period of textbooks } \\
\text { publishing* }\end{array}$ & 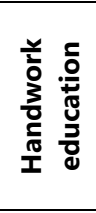 & 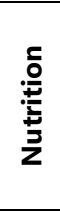 & 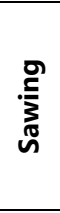 & $\frac{\mathbb{t}}{\mathbb{0}}$ & 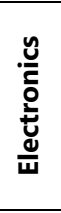 & 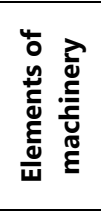 & 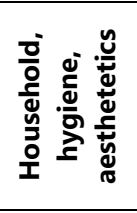 & 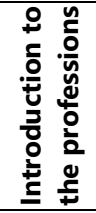 & 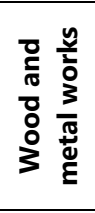 & . \\
\hline $1926-1930 \mathrm{~m}$. & $x$ & & & & & & & & & \\
\hline $1961-1970$ m. & & $\mathrm{x}$ & $\mathrm{x}$ & $\mathrm{x}$ & & & $\mathrm{x}$ & & & \\
\hline $1972-1978 \mathrm{~m}$. & & $x$ & $x$ & $\mathrm{x}$ & & & $x$ & $x$ & & \\
\hline $1981-1987 \mathrm{~m}$. & & $x$ & $\mathrm{x}$ & $\mathrm{x}$ & $\mathrm{x}$ & $x$ & $x$ & & $x$ & \\
\hline $1997-1998 m$ & & & & & & & & & $\mathrm{x}$ & \\
\hline $1999-2002 m$ & & $x$ & $\mathrm{x}$ & $\mathrm{x}$ & & & & & & \\
\hline $2000-2001 \mathrm{~m}$. & & $x$ & $x$ & $x$ & $\mathrm{x}$ & & $\mathrm{x}$ & $x$ & $x$ & \\
\hline $2008-2017$ m. & & $x$ & $\mathrm{x}$ & $\mathrm{x}$ & $\mathrm{x}$ & & $x$ & $x$ & $x$ & $x$ \\
\hline
\end{tabular}

* The years display the publishing period of textbooks with the new or updated content

Works for the 8th form' (1986); Galkauskas K. J., Zybartas 'Technical Works for the 9th form' (1987). The contents of these textbooks consisted of woodworking, metalworking, electrical installation works, the elements of machinery science and automatic equipment. The textbooks for the 7th and 8th forms set out in detail the trades related to woodworking, metalworking and electrical installation works, and the content was oriented towards industrial production. These were perhaps the only textbooks that reflected the purpose set out by the general programmes for Handwork of that time to prepare pupils for trades. But they were dedicated for boys. In 1989, before the restoration of independent Lithuania, Professor M. Lukšienė, with a group of pedagogues, scientists and cultural activists, elaborated the National School Concept (Lithuanian general education school concept, 1989). She called on the people to work towards the survival of the nation and its identity and to create an educational system that would turn out independent, civic and cultured people (The National School, 1989). The concept resulted in a further change in the content of general education. After the restoration of Lithuania's independence, our own national culture began to be developed on the basis of the structure of the educational content and a new curriculum. In 1992, the Experimental Handwork and Domestic Culture Curriculum was drawn up and adopted by the Ministry of Education (Galkauskas, 2004). It lasted only for two years, whereas textbooks that followed this curriculum were not published. In 1992, the content of Handwork and Domestic Culture was officially differentiated by gender: domestic work was aimed at teaching girls (the programme envisaged teaching the basics of nutrition, cooking, clothing modelling, construction and sewing, basics of household management and economics, Handicraft and domestic culture), whereas technical works were aimed at teaching boys (the programme envisaged teaching woodworking, metalworking, electrical installation works and domestic tidying works). The programmes emphasised the ability of pupils to analyse reality and environment, resolve problems, understand the changes characteristic of modern society and affect them actively. Pupils had to be taught to use different technologies and databases, develop critical thinking and increase creativity (Urbietis, 2005).

Lithuanian General Education School Programmes, which were updated in 1994, read: 'Work and domestic life are two intricately entwined areas of life related to the satisfaction of basic needs of the man and society. Meaningful work nurtures physical, mental, and spiritual powers of the man, develops creativity and a personality who is healthy and harmonious physically and spiritually. A high personal and societal work culture is one of the most important factors determining the material welfare of man and the country. It assists man in creating decent living conditions, cosy, aesthetic, healthy living environment and promoting domestic culture' (Programmes of Lithuanian General Education Schools, 1994). The Handwork and Domestic Culture Programme of that time envisaged the development of a personal ability to adopt and to creatively develop ethnic cultural traditions in one's household and at work. Handwork teaching had to promote responsibility for the domestic culture of one's own country, while understanding it as part of a wider whole of national culture. The programme envisaged the integration of historical and cultural production and business traditions of our nation and the world into the content of Handwork. Yet, illustrations in textbooks of the time, i.e. depictions of girls in the kitchen, were stereotypical reflections of domestic work that was largely performed by females - and was expected to be performed by females.

Girls, while learning to prepare a table for a festivity, had to be familiarised with national customs and traditional meals. Work with fabric familiarised them with the Lithuanian national costume and its place in today's life and the like. Metalworking and woodworking had to familiarise boys with wood processing and metalworking traditions and the works of Lithuanian folk artists. While learning to do domestic work, pupils were encouraged to creatively promote national traditions in home decorating and finishing works. The programmes of the subject displayed a clear shift from industrial training to the preparation for independent living based on national identity. Unsurprisingly, handcraft textbooks were filled with theoretical knowledge and moral principles. These enabled 
girls not so much to prepare for their future trade, as to learn to manage their households, take care of nature, and develop their creativities such as food preparation, sewing, knitting and domestic housework such as cleaning.

In 1997, the subject was renamed Works and Domestic Culture, and manual training was envisaged from the fifth to the twelfth forms (Urbietis, 2005). New general programmes of Handwork and Domestic Culture differed from the previous ones - the main focus was placed on integral knowledge in economics, ecology, healthy lifestyle, graphic design, technical graphics and artistic creativity. For the first time, the programmes presented the content of the subject, which was not further specified. Only the areas of the subject and guidelines to implement them were pointed out: household, nutrition, work with fabric, threads, yarn, metalworking and woodworking. Students were taught to create a useful product, to know the environment, 'the aesthetics of which had to become a significant part of manual-technological training, the acquaintance of a future producer and consumer with the creation of things and environment' (General Programmes of Lithuanian General Education Schools for the 1st10th forms, 1997). The textbooks of that time (J. K. Galkauskas 'Woodworking for the 5th-10th forms' (1997) and J. K. Galkauskas 'Metalworking for the 5-10th forms' (1998)) taught creativity, woodworking as a craft, and pupils were familiarised with national traditions. For example, the content of the textbook 'Woodworking for the 5th-10th forms' consisted of the following: the significance of wood and its purpose, the beginning of woodworking, woodworking tools and their use, wood lathing, the fitting of the components of wooden products, the trim of wooden products, the creation of products and their purposes. Practical teaching became the foundation for the Handicraft to develop, to revive and to retain national traditions. The teaching of Handwork and Domestic Culture by gender was considered the norm, and therefore, at that time, the content was traditionally oriented towards the transmission of a taken-for-granted knowledge of domestic life separately to boys and girls.

Although the subject was still called Handwork and Domestic Culture, the series of textbooks, published from 1999 to 2002, was named 'Technologies'. The series consisted of the following books: B. Melkuvienè et al. 'Technologies. Culinary for the 5th form'. (1999); R. Dačiulytè, R. Indičianskienè 'Technologies. Sewing for the 5th form' (2000); A. Pacevičiūte et al. 'Technologies. Nutrition for the 6th form' (2001); A. Pacevičiūtè et al. 'Technologies. Sewing for the 6th form' (2002a); A. Pacevičiūtė et al. 'Technologies. Sewing for 7-8th forms' (2002b). The content of the textbooks accurately reflected the general programmes of 1997, but, again, did not differ substantially from the textbooks published from 1980 to 1987. The content of the textbooks covered only the areas of teaching reserved for girls - cooking; nutrition; table serving; the preservation of food; sewing and work with fabric, threads and yarn.

In 2000, separate textbooks titled 'Handwork and Domestic Culture' were published for the fifth, sixth, seventh and eighth forms (Galkauskas et al., 2001a, 2001b, 2001c, 2001d). The textbooks consistently covered the content of the national programme of the subject; the content of the textbooks consisted of home economics, household care, redecoration, electrical equipment, nutrition and cooking, sewing, crochet and embroidery, knitting, wood and its processing. The content of the textbooks, as much as in the programmes, included no presentation of trades; instead, a clear orientation towards teaching creative-industrial processes, and creating and managing the household prevailed. The textbooks provided knowledge essential for independent living, which was needed for Lithuanian society at that time. For the first time, the content of the textbooks was not differentiated by gender; it could only be presumed (when looking at examples and photographs) which chapters were stereotypically assigned to either gender.

In 2003, new general programmes and education standards were adopted, in which Handwork and Domestic Culture were called Technologies (General Programmes and Educational Standards, 2003). These programmes were all the more important in view of the fact that the content of technologies was not officially differentiated by gender (the letter of the Ministry of Education and Science of 12 December 2003 to educational units No. SR-12-05216 on the change in technology education). In the general programmes of technologies, it was also pointed out that conditions should be created for all the pupils (without differentiating them by gender) to learn different technologies. However, the recommendation to organise technology education in mixed groups was not implemented in all schools (Technology education..., 2013). The purpose of the Technologies programme is to enable pupils to develop a basic knowledge of technology, i.e. to promote value-related attitudes and key competences, which are necessary for every person $\langle\ldots\rangle$ in the ever-changing socio-cultural environment, to be able to use low technologies as consumers, to experience the creative diversity of the search for problem solution and the joy of their solution and, based on that, to develop positive attitudes for the continuous change of technologies' (Primary, Lower Secondary and General Education, 2003). In the process of technology education, pupils were prepared to be members of their families, citizens who are able to flexibly adapt to a changing society and ready to further improve themselves (Urbietis, 2005). Although the subject was called Technologies, the content of the programmes retained a clear focus on the development of the consumer, with no elements of industrial production.

In 2008, in the updated programme of Technologies, it was stated: 'It is important for pupils to know the impact of emerging or developed technologies on nature, the man and material environment, to understand how to assess 
the benefits of technologies and any possible negative effect on personal and societal health, safety and welfare' (General Programmes for Primary and Lower Secondary Education, 2008). Technologies programme has remained unchanged until this year, 2019. The Technologies nowadays is a complex interdisciplinary school subject, which gives the possibility for pupils to appy their knowledge in practice and to get aquinted with the labor market. The subject of Technologies is ment to develop abilities of pupils to distinguish, identify the needs of society, generate, optimize ideas and make them work. Design and technology have a common goal of creating and producing (General Programmes for Primary and Lower Secondary Education, annex 8, 2008).

The subject is thought from the 1 st to 12 grades. At primary school pupils in the first to fourth forms (age of 6/7 to 10) have compulsory subject called Art and technologies. The compulsory content of the general programmes of Technologies in the fifth to eighth forms (age of 11 - 16) consists of nutrition, textiles, construction materials and electronics. (General Programmes for Primary and Lower Secondary Education, annex 8).

Pupils of the secondary school from ninth to tenth forms (age of 16/17-18) have Technologies as elective course and are allowed to choose the content of technologies from among the following five possible areas: nutrition, textiles, construction materials, electronics and product design. They study integrated technology course for the first year and after it they can choose one of the modules of nutrition, textile, electronics, constructive materials and product design. Approximately $25 \%$ of Integrated technology course is devoted to theoretical framework of the national industries and economy Approximately 25\% of the estimated time is spent on meeting with representatives of vocational schools, industry, service companies, business, consumer and public organizations. Approximately $50 \%$ of the estimated time is devoted to deepening the knowledge and abilities of the chosen module, to carry out the projects at school or in work environment (Integrated Technology Cours, 2007).

Gymnasium (age of 16/17-18) also provides the opportunity for pupils to chose the Integrated course of technology education, arts and technologies ${ }^{4}$. The goal of this course is to introduce pupils with the work environments, to assess the tendencies and opportunities of their cariere, to develop their creativity, cultural competence and visual culture (National curriculum for secondary education, 2006).

To facilitate mastery over these areas, the following series of textbooks was published from 2008 to 2014: A. Pacevičiūte et al. 'Nutrition. Textile for the 5-6th forms' (2008); A. Pacevičiūtè et al. 'Construction Materials and Electronics, for the 5-6th forms' (2008); A. Pacevičiūtè et al. 'Textile for the 7-10th forms' (2010); A. Pacevičiūtè et al. 'Nutrition for the 7-10th forms' (2011); A. Pacevičiūtè et al. 'Construction Materials for the 7-10th forms' (2011); A. Pacevičiūtè et al.'Technologies for the 11-12th forms' (2014). For the first time, a 'Technologies' textbook for the 11-12th forms, in which trades were comprehensively presented, was published. The contents of the textbook were the following: textiles and clothing; applied art, handicraft, design and printing; tourism and nutrition; building and wood processing; business management, retail trade; mechanics and mechanical repair. The textbook on technologies was a qualitative leap in the Lithuanian teaching of Handicraft in terms of the analysis of technological processes. The content of textbooks is presented on the basis of a systematic introduction of technologal processes: design, information search, accumulation, application and presentation, the knowledge of materials, their application, the knowledge of technological processes, the performance of work processes and the presentation of results. However, an analysis of the content shows that it remained the same as in the earlier textbooks: cooking (Nutrition chapter in the Technologies textbooks); work with fabric, knitting, crochet (textile chapter); woodworking, metalworking (Construction Materials chapter in the Technologies textbooks); electrotechnics (Electrotechnics and Electronics chapter in the Technologies textbooks). In these textbooks, industrial production was introduced; however, practical examples responded to the needs of the individual consumer. The textbooks taught creation and production for oneself and the immediate environment, moving away from mass production. The content of the textbooks and their structure are essentially in line with the changed concept of the subject and requirements set for modern teaching materials. Although the content of technologies was officially aimed at both boys and girls, research conducted in 2013 showed that $75.9 \%$ of the teachers who participated in the survey pointed out that in the fifth to eighth forms, technology lessons are conducted in mixed groups, and almost one fourth of the teachers pointed out that in their schools pupils are grouped by gender. On the basis of the responses of the teachers, it is learnt that in secondary schools, boys and girls learn separately more often than in lower secondary schools or progymnasia; in towns, it occurs more often than in villages or townships; and in large schools (in reference to the number of pupils) more often than in small schools (Technology Education: Situation, Opportunities, Perspectives, 2013).

It is worth noting that there is strong tendency to teach mixed rather than separate groups. In fact, there is pressure from the school community not to discriminate against pupils on the basis of gender, but allow choice in the content of Technology (Decision of the Equal Opportunities Ombudsmen of the Republic of Lithuania, 2019). For example, the National Programme of Technologies places the responsibility for developing content squarely on teachers. The new programme raises challenges and opportunities based on student's outcomes, didactic principles

\footnotetext{
${ }^{4}$ Only Gimnasiums that have chosen the profile of technologies
} 
and general fields of content. The risk that the subject is being taught in according to old tradition remains high; just as high is the risk of losing cultural identity and crafts. With the shift in content towards industrial technologies issues of consumer education (new technologies emerge in the environment dominated by consumption in order to boost consumption (Kacerauskas, 2015) can be eliminated. Crafts, a peculiarity of Lithuania, will be eliminated from the programme as well as the aspects of creativity which is the main strength of the subject. The present century often being referred to as the "age of a creative society". Some scholars argue that there is no contradiction between creativity and technologies, (Kačerauskas, 2017). A society enters the age of creativity at the point when the growth of a creative economy is considered to be a key factor in its further development (Florida, 2005). The change in the perception of arts and business relationship encourages the synthesis of artistry and aesthetics, technology and entrepreneurship, expressed by new collocations, such as "creative economy", "creative society", "innovative product", and "creative solution". These new collocations are used in the 21st century to refer to arts, advertising, education, business, leadership, IT and technologies, design, and creative industries (Florida, 2005). These issues must be referenced the content of Technology education when updating it.

Changes in content have ensured that of Technologies subjects have become integral to where STEAM topics are being implemented in the curriculum. This practical subject at school allows pupils to understand technologies, to develop ideas and products, to understand the impact of technologies on nature, human, material environment, health and well being of individuals and society. Yet, the absence of such topics as media and creative industries and the digital technologies, suggests that the national curriculum is in need of new perspectives and tools for implementation.

\section{CONCLUSIONS}

The historic review of the Lithuanian textbooks of Works, Handicraft, Handwork and Domestic Culture, Technologies enables us to draw a few conclusions. As the social and economic needs of society changed, the purposes of the subject in national curriculum changed: the purposes of industrial training and preparation for agricultural work and vocational training were changed by the purpose of learning to manage households and to create and to promote traditional Handicraft. The content of the textbooks on handicraft, handwork and domestic culture, technologies, which were published from 1928 to 2017, changed insignificantly, the essential parts of the content remaining unchanged: nutrition (cooking, foodstuff), textiles (crochet, knitting, sewing), elektrotechnics (later electronics) and construction materials (woodworking, metalworking). The content of the textbooks of handicraft/technologies has always been differentiated by gender. The content of the textbooks, in great measure, depended on the continuity of prevailing traditions and the line of thinking of the authors and, as often was the case, showed little consistency with the national programme of the subject. Familiarisation with industrial production has always been one of the most important purposes of the general programmes of the subject, but the textbooks reflected it poorly. A school textbook of handicraft/technologies was a convenient reflection of the research of society's taken-for-granted knowledge, which may help understand the development rate and direction of Lithuanian society. This study has revealed the inconsistency between the content of school programmes prepared by the state and the content of textbooks during certain periods. Although state institutions steered Lithuanian public education towards industry-oriented manual training and attempted to direct both Lithuanian girls and boys to industrial production, the textbooks reflect the traditional view of what Lithuania's people needed, namely basic knowledge of how to manage domestic life, and promote Handicraft and national traditions.

Although the development of the subject is slightly different in different countries, the subject's objectives are very similar (Dislere, 2012; Pöllänen \& Urdziña-Deruma, 2017; Pridāne, 2017; Turkki, 2012). The subject nowdays is one of the main subjects to where STEAM topics are implemented. This practical subject at shool gives the opportunity for pupils to understand technologies, to develop ideas and producs and to develop their creativity. However, the national curriculum is lacking new approaches and tools of implementation. There is a lack of topics of media litheracy as well as digital technologies in the subject. There is no inconsistency in the content of textbooks and the programmes, however both have to be updated. The rapid development of both science and technology rises new challenges for the education and Technologies subject has to be the reflection of it. It is recommended to address media literacy issues and include topics of various creative industries as well as to use more digital technologies in the subject.

\section{REFERENCES}

Bernotas, V. (1997). Pedagogas Vincas Ruzgas (Teacher Vincas Ruzgas). Acta Paedagogica Vilnensia. t. 4. 52-59. https:/ / doi.org/10.15388/ActPaed.1997.04.9407

Binkauskienė, E. (1960). Namu ruoša V - VIII klasei (Handwork for the 5-8th forms). Kaunas: Valstybinè pedagoginès literatūros leidykla.

Binkauskienè, E. (1972). Buities darbai V klasei (Domestic Work for the 5th form). Kaunas: Šviesa. 
Binkauskienė, E. (1973). Buities darbai VI klasei (Domestic Work for the 6th form). Kaunas: Šviesa.

Binkauskienè, E. (1980). Buities darbai V klasei (Domestic Work for the 5th form). Kaunas: Šviesa.

Binkauskienè, E., Paurienè, A., \& Zybartas, A. (1985). Buities darbai. VI klasei (Domestic Work for the 7th form). Kaunas: Šviesa.

Blumberg, R. L. (2007). Gender bias in textbooks: a hidden obstacle on the road to gender equality in education. Background paper prepared for the Education for All Global Monitoring Report 2008 Education for All by 2015: will we make it?

Bruzgelevičienè, R. (2008). Lietuvos švietimo kūrimas 1988-1997 (Creation of Lithuanian Education 1988-1997). Vilnius: Sapnų sala.

Cibulskaitè, N., \& Baranovska, K. (2009). Matematikos vadovėlių V klasei vertinimas dalykiniu, pedagoginiu ir psichologiniu požiūriais (Assessment of textbooks of Mathematics for the $5^{\text {th }}$ form from professional, pedagogical and psychological point of view). Pedagogika, t. 95,153-159.

Dačiulytė, R., \& Indičianskienè, R. (2000). Technologijos. Siuvimas 5 klasei (Technologies. Sowing for the $5^{\text {th }}$ form). Vilnius: Lama.

Dislere, V. (2012). Methodology structure for training teachers of Home economics and Technologies. Rural environment. Education. Personality. Proceedings of International Scientific Conference, 5, 201-208.

Florida, R. (2005). The flight of the creative class: the new global competition for talent. New York: HarperCollins Publishers. https:/ / doi.org/10.4324/9780203997673

Galkauskas, J. K. (1997). Medžio darbai. V-X kl (Wood work for the 5-10 form). Kaunas: Šviesa.

Galkauskas, J. K. (1998). Metalo darbai. V-X kl (Wood work for the 5-10 form). Kaunas: Šviesa.

Galkauskas, J., Kadzijauskienė, L., Senulytė, E., \& Žirgulienė, K. (1984). Buities darbai VIII klasei (Domestic Work for the 8 form). Kaunas: Šviesa.

Galkauskas, J., Kadziauskienè, L., Senulytė, E., \& Žirgulienė, K. (1974). Buities darbai VII klasei (Domestic Work for the 7 form). Kaunas: Šviesa.

Galkauskas, J., Kadziauskienė, L., Senulytė, E., \& Žirgulienė, K. (1975). Buities darbai VIII klasei (Domestic Work for the 8 form). Kaunas: Šviesa. 62 p.

Galkauskas, J., Kadzijauskienė, L., Senulytė, E., \& Žirgulienė, K. (1983). Buities darbai VII klasei (Domestic Work for the 7 form). Kaunas: Šviesa.

Galkauskas, K. J. (2004). Rankų darbai kaip mokymo dalykas (istorinis aspektas) (Hand work as a school subject (historical aspect). Pedagogika, 74, 25-28.

Galkauskas, K. J., Indičianskienė, R., Mielkuvienė, B., Sederevičiūtè, Ž., Vaitkevičiūtè, A., Sveikauskaitė, A., ... Žygaitienè, B. (2001a). Darbai ir buities kultūra V klasei (Handwork and Domestic culture for the $5^{\text {th }}$ form). Vilnius: Onè.

Galkauskas, K. J., Indičianskienė, R., Mielkuvienė, B., Sederevičiūtè, Ž., Vaitkevičiūtè, A., Sveikauskaitė, A., ... Žygaitienè, B. (2001b). Darbai ir buities kultūra VI klasei (Handwork and Domestic culture for the $6^{\text {th }}$ form). Vilnius: Onè.

Galkauskas, K. J., Indičianskienė, R., Mielkuvienė, B., Sederevičiūtè, Ž., Vaitkevičiūtè, A., Sveikauskaitė, A., ... Žygaitienè, B. (2001c). Darbai ir buities kultūra VII klasei (Handwork and Domestic culture for the $7^{\text {th }}$ form). Vilnius: Onè.

Galkauskas, K. J., Indičianskienė, R., Mielkuvienė, B., Sederevičiūtè, Ž., Vaitkevičiūtè, A., Sveikauskaitė, A., ... Žygaitienè, B. (2001d). Darbai ir buities kultūra VIII klasei (Handwork and Domestic culture for the $8^{\text {th }}$ form). Vilnius: Onè.

Galkauskas, K. J., \& Zybartas, A. (1986a). Techniniai darbai 7 klasei (Technical Works for the 7 form). Kaunas: Šviesa.

Galkauskas, K. J., \& Zybartas, A. (1986b). Techniniai darbai 8 klasei (Technical Works for the 8 form). Kaunas: Šviesa.

Galkauskas, K. J., \& Zybartas, A. (1987). Techniniai darbai 9 klasei (Technical Works for the 9 form). Kaunas: Šviesa.

Gerrard, J. (2004). Health Sciences. Literature Review Made Easy: The Matrix Method. Sudbury, Massachusetts: Jones and Barlett Publishers.

Herbs, J. (2006). School Choice and School Governance - A Historical Study of the United States and Germany. Palgrave Macmillan.

Integruota Technologijų kurso bendroji programa mokiniams, besimokantiems pagal pagrindinio ugdymo programos antrają dali (Integrated Technology Course for learners under the second part of the core curriculum). (2007). Lietuvos Respublikos švietimo ir mokslo ministro 2007 m. rugsèjo 6 d. įsakymu Nr. ISAK-1790. 
Yang, L., \& Myint, S. K. (2016). Content Analysis of The Diagrammatic Representations of Primary Science Textbooks. Eurasia Journal of Mathematics, Science $\mathcal{E}$ Technology Education, 12(8), 1937-1951. https:/ / doi.org/10.12973/eurasia.2016.1288a

Jasaitis, J. (1978). Techniniai darbai IV-VI klasei (Technical Works for the 4-6 form). Kaunas: Šviesa.

Jasaitis, J., \& Galkauskas, K. J. (1985). Techniniai darbai IV-VI klasei (Technical Works for the 4-6 form). Kaunas: Šviesa.

Jurènienè, V. (2009). Sovietinès moters „kūrimas“ sovietų lietuvoje ir sovietų sajjungoje (("Creation" of Soviet woman in Soviet Lithuania and Soviet Union). Gender Studies E Research, 7, 36-45.

Kantola, J., Nikkanen, P., Kari, J., \& Kananoja, T. (1999). Through education into the world of work. Uno Cygnaeus, the Father of Technology Education. Jyväskylä University. Institute for educational research. Jyväskylä: Jyväskylä University Press, 9 - 17.

Kacerauskas, T. (2015) Technologies in Creative Economy and Creative Society. Technological and economic development of Economy, 2-14. https:/ / doi.org/10.3846/20294913.2015.1036325

Kačerauskas, T. (2017). Kreativnost i koncepciya kreativnovo obščestva v sociologii. Sotsiologicheskie issledovaniya, 10, 26-35.

Lietuvos bendrojo lavinimo mokyklos bendrosios programos: I-X klases (Programmes of Lithuanian General Education Schools: I-X grades). (1997). Lietuvos Respublikos švietimo ir mokslo ministerija, Pedagogikos institutas. Ed.: Ž. Jackūnas, D. Kuolys, M. Lukšienè. Vilnius: Leidybos centras.

Lietuvos bendrojo lavinimo mokyklos programos: projektai (Programmes of Lithuanian General Education Schools). (1994). Vilnius: Lietuvos Respublikos švietimo ir mokslo ministerijos Leidybos centras.

Lietuvos vidurinès bendrojo lavinimo mokyklos koncepcija (Lithuanian general education school concept). (1989). Kaunas. 1, 39.

Lietuvos respublikos lygiu galimybių kontrolieriaus sprendimas dėl galimos diskriminacijos lyties pagrindu Vilniaus Šv. Kristoforo gimnazijoje nustatant vaikų skirstymo technologijų pamokų metu tvarką tyrimo 2019 m. sausio 25 d. Nr. (18)SN-206)SP-14, Vilnius (Decision of the Equal Opportunities Ombudsmen of the Republic of Lithuania on possible discrimination on the grounds of sex Vilnius St. In Christopher Gymnasium, determining the order of children's apportionment during technology lessons in 2019, January 25 No. (18) SN-206) SP-14, Vilnius).

Lind, E. (2009). Studying and Teaching Craft: Possibility and Necessity. Proceedings of the Conference Crafticulation $\mathcal{E}$ Education, Helsinki, 23- 27 Sept. 2008.

Lind, E. (2012). The content and aims of Handicraft as a subject in Estonian General Education schools pursuant to social requirements. CFMAE: The Changing Face of Music and Art Education, 4(2), 87-99.

Lukšienè, M. (1970). Lietuvos švietimo istorijos bruožai XDC a. pirmoje pusèje (Features of the Lithuanian Educational History in the first half of XDC century. Pedagogikos darbai, IV. In: Galkauskas K. J. Rankų darbai kaip mokymo dalykas. Aukštosios mokyklos didaktikos tendencijos. 25-28 pp.

Lukšienė, M., \& Jonynienè, V. (1992). Vadovèlis (The textbook). In: Jašinauskas L. (2013). Lietuvos bendrojo ugdymo vadovèlio sampratos kaita (1990-2012). Istorija. Mokslo darbai, 89, 48-57.

Mayring, P. (2000). Qualitative Content Analysis [28 paragraphs]. Forum Qualitative Sozialforschung / Forum: Qualitative Social Research, 1(2), Art. 20.

Mcculloch, G. (2004). Documentary Research in Education. History and the Social Sciences. London and New York: Routledge. https://doi.org/10.4324/9780203464588

Melkuvienè, B., Gudmonienè, Ž., \& Sederevičiūtè, Ž. (1999). Technologijos. Kulinarija, 5 kl. (Technologies for the $5^{\text {th }}$ form). Vilnius: Lama.

Mielkuvienė, B., Pacevičiūtè, A., \& Drakšienė, R. (2011). Mityba. Vadoveilis XII-X klasei (Nutrition for the 7-10 th forms). Kaunas: Šviesa.

Numgaudienè, A, Žygaitienè, B. (2014). Content Analysis of Technology Teacher Training Programmes of Some European Countries. Pedagogika, 113(1), 112-122.

Pacevičiūtė, A., Andrijauskienè, E., Gedmantienè, E., \& Stasiūnienė, B. (2001). Technologijos. Mityba. 7 klasei (Technologies. Nutrition for the $7^{\text {th }}$ form).. Vilnius: Lama.

Pacevičiūtė, A., Augustinaitis, V., Buračienė, A., Krakauskienė, D., Kriukas, D., Lekarevičius, J., ... Staškauskienė, Ž. (2014). Technologijos XI-XII klasei (Technologies for the 9-12 forms). Kaunas: Šviesa.

Pacevičiūtė, A., Augustinavičius, V., Čiupaila, R., Lekarevičius, J., Narvilas, M., \& Račkauskas, V. (2008). Konstrukcines medžiagos ir elektronika, 5-6 klasei (Construction Materials and Electronics, for the 5-6th forms). Kaunas: Šviesa. 
Pacevičiūtė, A., Augustinavičius, V., Lekarevičius, J., \& Narvilas, M. (2011). Konstrukcinés medžiagos 7-10 klasei (Construction Materials and Electronics, for the 7-10th forms). Kaunas: Šviesa.

Pacevičiūtė, A., Buračienè, A., Jucienė, N., Narvilas, M., Šiaulienė, V., \& Vaitkevičienè, R. (2008). Mityba. Tekstilè.Vadovelis 5-6 klasei (Nutrition. Textile for the 5-6th forms). Kaunas: Šviesa.

Pacevičiūtè, A., Buračienė, A., \& Vaitkevičienė, R. (2010). Tekstile VII-X klasei (Textile for the 7-10th forms). Kaunas: Šviesa.

Pacevičiūtė, A., Dačiulytė, R., \& Melnikaitè, E. (2002a). Technologijos. Siuvimas 5 klasei (Technologies. Wowing for the 5th form). Vilnius: Lama.

Pacevičiūtè, A., Dačiulytè, R., \& Melnikaitè, E. (2002b). Technologijos. Siuvimas 7-8 klasei (Technologies. Wowing for the 7-8th form). Vilnius: Lama.

Pöllänen, S., \& Urdziņa-Deruma, M. (2017). Future-Oriented Reform of Craft Education: The Cases of Finland and Latvia. In: Kimonen E., Nevalainen R. (eds) Reforming Teaching and Teacher Education. Bright Prospects for Active Schools Sense Publishers, Rotterdam. https:/ / doi.org/10.1007/978-94-6300-917-1_5

Pradinio ir pagrindinio ugdymo bendrosiosiose programos. Technologijos (General Programmes for Primary and Lower Secondary Education) (2008). Lietuvos Respublikos švietimo ir mokslo ministro 2008 m. rugpjūčio 26 d. Isakymas Nr. ISAK-2433.

Pradinio ir pagrindinio ugdymo bendrosiosiose programos. Technologijos, 8 priedas (General Programmes for Primary and Lower Secondary Education, annex 8) (2008). Lietuvos Respublikos švietimo ir mokslo ministro $2008 \mathrm{~m}$. rugpjūčio 26 d. İsakymas Nr. ISAK-2433.

Pridāne, A. (2017). The Study on Competence - Based Curriculum Implementation in the Subject Home Economics and Technologies. Rural Environment. Education. Personality. Proceedings of $10^{\text {th }}$ international scientific conference, Jelgava, 12-13 May.

Priešmokyklinis, pradinis, ir pagrindinis ugdymas (Primary, Lower Secondary and General Education). (2003). In: Lietuvos bendrojo lavinimo mokyklos Bendrosios programos ir išsilavinimo standartai. Vilnius: Švietimo aprūpinimo centras.

Raipa, A., \& Smalskys, V. (2003). Tarpukario Lietuvos valdininkų ịvaizdis ir jų veiklos efektyvumo problemos (The image of Lithuanian clerks and the problems of their efficiency). Viešoji politika ir administravimas, 6, 73-80.

Ruzgas, V. (1928). Kaip organizuoti fizinis ranku darbas mokykloje (How to organise the hand work at school). Kaunas: Naujoji Lietuva. 1928, p. 69-141.

Sadker, D., \& Zittleman, K. (2007). Gender bias from Colonial America to today's classrooms. In: James B., Cherry A. M. B. Multicultural education: issues and perspectives. Hoboken: John Wiley \& Sons, Inc. 135-169.

Schutz, A., \& Luckmann, T. (1973). The Structures of the LifeWorld. Vol. 1. Evanston: Northwestern University Press.

Širiakovienė, A. (1991). V.Ruzgas apie darbinị mokymą (V. Ruzgas about the hand work). Acta Paedagogica Vilnensia. 121-125. https:/ / doi.org/10.15388/ ActPaed.1991.01.9353

Stašaitis, S. (2008). Istorija Lietuvos mokykloje 1940-1941 metais: tautiškumo ir sovietinès ideologijos diegimas (History of Lithuanian School in 1940-1941: Implementation of National and Soviet Ideology). Istorija, mokslo darbai, no. 70.

Statauskienè, L. (2009). Technologinio ugdymo ivadas (The introduction to the Technologies' education). Vilnius: VPU leidykla, 74.

Stromquist, N. P. (1989). Determinants of educational participation and achievement of women in the third world: a review of the evidence and a theoretical critique. Review of Educational Research, 59(2), 143-183. https:/ / doi.org/10.3102/00346543059002143

Svèrienė, A. (2006). Teoriniai mokyklinio vadovèlio aspektai (Theoretical aspects od textbooks). Knygotyra, 47, 2847.

Taar, J. (2017). Interthinking in Estonian Home Economics Education. Helsinki Studies in Education, number 16,

Tautine mokykla. Lietuvos bendrojo lavinimo vidurines mokyklos koncepcija (The National Scool. The conception of Lithuanian general education school) (1989). [2014 m. spalio $24 \quad \mathrm{~d}$.]. Retrieved from http:/ / www.smm.lt/uploads/documents/Veikla_strategija/svietimo_reformos_pradzia/tautine_mokykl a.pdf

Technologinis ugdymas: situacija, galimybès, perspektyvos, Švietimo ir mokslo ministerijos informacinis leidinys (Technology education: Situation, Opportunities, Perspectives, the information sheet of the Ministry of Education and Science). (2013). Spalis Nr. 7 (93) ISSN 1822-4156.

Thorsteinsson, G., \& Ólafsson, B. (2014). Otto Salomon in Nääs and his first Icelandic students in Nordic Sloyd, History of Education, 43(1), 31-49. https:/ / doi.org/10.1080/0046760X.2013.835451 
Thorsteinsson, G., Page, T., \& Brynjar, O. (2009). Moving from Craft to Technology Education in Icelandic Schools. Studies in Informatics and Control, 18(4), 369-378.

Turkki, K. (2012). Home economics - a forum for global learning and responsible living [online]. In: Pendergast, Donna (Editor); McGregor, Sue LT (Editor); Turkki, Kaija (Editor). Creating Home Economics Futures: The Next 100 Years. Bowen Hills, QLD: Australian Academic Press, 38-51.

Urbietis, P. (2005). Darbinis (technologinis) ugdymas Lietuvoje bendrojo lavinimo mokykloje (1918-2003) (The work (technological) education in Lithuanian general education school 2018 - 2003). (2005). Šiauliai: Šiaulių universiteto leidykla.

Urdzina-Deruma, M. (2006). Historical Development of Handicraft Education in General Schools in Latvia. Technical and Vocational Education Research Report, China, 31-43.

Vaičiulienė, A. (1973). Darbinis mokymas kaimo vidurinèse mokyklose. Metodine medžiaga (The work education in Lithuanian general education schools. Methodological material). Vilnius: Pergalè.

Valantinaite, I., \& Žilinskaitė, R. (2012). Technologinio ugdymo samprata atnaujintose programose (Technological education concept in updated programs). Pedagogika, 105, 14-19.

Vidurinio ugdymo programos aprašas (National curriculum for secondary education). (2006). Lietuvos Respublikos švietimo ir mokslo ministro 2006 m. birželio 30 d. ịsakymu Nr. ISAK-1387.

\section{http://www.ejmste.com}

